\title{
URBANIZÁCIÓ BULGÁRIÁBAN
}

\author{
(The Urbanization Process in Bulgaria)
}

\section{CHAVDAR MLADENOV - MARGARITA ILIEVA - NADEZHDA ILIEVA - BORIS KAZAKOV}

\begin{abstract}
Kulcsszavak:
Bulgária városodás urbanizáció Balkán Délkelet-Európa

A tanulmány Bulgária urbanizációs tendenciáit foglalja össze. Elemzi a bolgár városhálózat fejlödését a múltban és a közelmúltban. Az általános tendenciák mellett kiemeli a balkáni, azon belül Bulgáriára érvényes sajátosságokat. Napjaink fejlödési jellegzetességeit két esettanulmányon keresztül mutatja be. Az első a vidéki kisvárosok átalakulását vizsgálja, különösen annak demográfiai és migrációs sajátosságait. Bulgáriában a vidéki térségek egyik nagyon fontos problémája a elnéptelenedés, kiüresedés. Nem mentes ettöl a jelenségtöl a kisvárosi hálózat sem, ami csak részben magyarázható a rendkívül rossz. bolgár demográfiai mutatókkal. Nagy jelentősége van az elvándorlásnak is, aminek célpontja elsősorban a hazai nagyvárosokban (föváros, tengerpart), másrészt külföldön keresendö. A második esettanulmány a bolgár tengerpart városállományának átalakulását vizsgálja. Itt a városok számának, a városodottság mértékének növekedését tapasztalhatjuk. Bemutatja ennek hátterét, az adminisztratív várossá nyilvánítástól a sikeres, szerencsés földrajzi helyzetü agglomerációk fejlödéséig. Mindemellett utal a tengerparti sáv kevésbé szerencsés településeinek sorsára is.
\end{abstract}

\section{Bevezetö}

Az urbanizáció, mint egy összetett gazdasági és társadalmi jelenség a városi lakosság növekedésében nyilvánul meg. Ez egy sokoldalú folyamat, amely megváltoztatja az életmódot, a teljes népesség képzettségi és kulturális szintjét is a városi életmód elterjesztésével. A városi térség összetett, önszabályozó térség, amelyen belül előfordulnak egyenlötlenségek, különböző feszültségek, a gazdasági tevékenység és földhasználat átalakul, fejlesztések hatására megindul a népesség migrációja. A városi térség szervesen kötődik a központi városhoz és a változások párhuzamosan zajlanak a központban és a peremeken.

A városi és a vidéki népesség aránya visszatükrözi az országterület városodottsági szintjét és a nemzetgazdaság szerkezetét. Bulgáriában 1879-től egészen az 1960-as évekig a vidéki népesség aránya jelentősen meghaladta a városi népesség arányát (az 1946. évi népszámláskor is még 75,3/24,7\% volt az arány). Mindez a mezőgazdasági irányultságú gazdaság következménye volt (Mladenov-Dimitrov 2009a). Az arányszámok változása leolvasható az 1. táblázatból ${ }^{l}$. 
1. TÁBLÁZAT

A népesség megoszlása a települések jellege szerint, Bulgáriában, \% (Settlements Structure of the Population in Bulgaria, \%)

\begin{tabular}{cccccc}
\hline \multirow{2}{*}{ Népszámlálás } & \multicolumn{2}{c}{ Megoszlás } & \multirow{2}{*}{ Népszámlálás } & \multicolumn{2}{c}{ Megoszlás } \\
\cline { 2 - 3 } & Városi & Vidéki & & Városi & Vidéki \\
\hline 1880 & 83,3 & 16,7 & 1946 & 75,3 & 24,7 \\
1887 & 81,2 & 18,8 & 1956 & 66,4 & 33,6 \\
1892 & 80,3 & 19,7 & 1965 & 53,5 & 46,5 \\
1900 & 80,2 & 19,8 & 1975 & 42,0 & 58,0 \\
1905 & 80,4 & 19,6 & 1985 & 35,2 & 64,8 \\
1910 & 80,9 & 19,1 & 1992 & 32,8 & 67,2 \\
1920 & 80,1 & 19,9 & 2001 & 31,0 & 69,0 \\
1926 & 79,4 & 20,6 & 2008 & 28,9 & 71,1 \\
1934 & 78,6 & 21,4 & & & \\
\hline
\end{tabular}

Forrás: Nemzeti Statisztikai Hivatal.

Egy község várossá nyilvánítása Bulgáriában csak közigazgatási eljárás keretében történhet. Mégis, egészen 1995-ig nem volt olyan kritérium rendszer, amely alapján egy falu városi címet kaphatott. Az 1995. évi, a közigazgatási területrendezésről szóló törvény és annak módosításai értelmében ,ahhoz, hogy egy falu városi címet nyerjen el, rendelkeznie kell megfelelő társadalmi és műszaki infrastruktúrával, valamint legalább 3500 fôt elérő lakosságszámmal, üdülőtelepülések esetén pedig legalább 1000 fó állandó lakossal”.

A népesség továbbra is ,pontszerüen” koncentrálódik néhány városban, tehát az urbanizáció a hagyományos formájában zajlik továbbra is - a vidéki népesség a meglévő városok irányába vándorol, de a rurális terek demográfiai kiüresedése miatt a kisvárosból nagyváros irányába zajló migráció a legjelentősebb (Kopralev 2002).

A népesség településméret szerinti megoszlásának átalakulásából jól látható a nagyvárosi koncentráció folyamata (2. táblázat). A városi népesség több mint $70 \%$-a abban a 33 városban él, amelyek lakosságszáma meghaladja a 30 ezer föt, közülük is 44,7\% a 7 legnagyobb városban, míg a fennmaradó $27,1 \%$ a 26 középméretủ városban lakik (2008. évi adatok szerint). Ez is azt bizonyítja, hogy a nagyvárosok, ahol a gazdasági, társadalmi, infrastrukturális beruházások koncentrálódnak, kulcsszerepet játszanak a fejlődésben és meghatározzák az urbanizáció fő jellemzőit. A népesség, az infrastruktúra és az ipar jelenleg zajló nagyvárosi és - bizonyos mértékig - középvárosi koncentrációja súlyosbítja a centrum-periféria problémát (Kopralev 2007). 
2. TÁBLÁZAT

A városi települések nagyság szerinti megoszlása Bulgáriában (Distribution of Urban Settlements by Size)

\begin{tabular}{|c|c|c|c|c|c|c|c|c|c|c|}
\hline \multirow[b]{2}{*}{$\begin{array}{l}\text { Kategó- } \\
\quad \text { ria }\end{array}$} & \multicolumn{2}{|c|}{1946} & \multicolumn{2}{|c|}{1975} & \multicolumn{2}{|c|}{1992} & \multicolumn{2}{|c|}{2001} & \multicolumn{2}{|c|}{2008} \\
\hline & $\begin{array}{c}\text { Városi } \\
\text { telepü- } \\
\text { lések }\end{array}$ & Népesség & $\begin{array}{c}\text { Vá- } \\
\text { rosi } \\
\text { tele- } \\
\text { pülé- } \\
\text { sek } \\
\end{array}$ & $\begin{array}{l}\text { Népes- } \\
\text { ség }\end{array}$ & $\begin{array}{c}\text { Vá- } \\
\text { rosi } \\
\text { tele- } \\
\text { pülé- } \\
\text { sek } \\
\end{array}$ & $\begin{array}{l}\text { Népes- } \\
\text { ség }\end{array}$ & $\begin{array}{c}\text { Vá- } \\
\text { rosi } \\
\text { tele- } \\
\text { pülé- } \\
\text { sek } \\
\end{array}$ & $\begin{array}{l}\text { Népes- } \\
\text { ség }\end{array}$ & $\begin{array}{c}\text { Vá- } \\
\text { rosi } \\
\text { tele- } \\
\text { pülé- } \\
\text { sek }\end{array}$ & $\begin{array}{l}\text { Népes- } \\
\text { ség }\end{array}$ \\
\hline \multicolumn{11}{|c|}{ száma } \\
\hline$<10 x$. & 67 & 339163 & 126 & 690089 & 151 & 734687 & 158 & 741665 & 174 & 773641 \\
\hline $10-30 \mathrm{x}$. & 27 & 425301 & 56 & 888368 & 53 & 882622 & 49 & 822925 & 46 & 752514 \\
\hline $30-100 x$ & 10 & 408296 & 25 & 1428576 & 25 & 1465079 & 24 & 1347550 & 26 & 1463857 \\
\hline $100-200 x$ & 1 & 126563 & 4 & 533970 & 6 & 857760 & 6 & 819509 & 4 & 597148 \\
\hline$>200 x$ & 1 & 366801 & 3 & 1519377 & 3 & 1764415 & 3 & 1742885 & 3 & 1816028 \\
\hline Összesen & 106 & 1666124 & 214 & 5060380 & 238 & 5704563 & 240 & 5474534 & 253 & 5403188 \\
\hline \multicolumn{11}{|c|}{ aránya (\%) } \\
\hline$<10 x$ & 63,2 & 20,4 & 58,9 & 13,6 & 63,4 & 12,9 & 65,8 & 13,5 & 68,8 & 14,3 \\
\hline $10-30 \mathrm{x}$ & 25,5 & 25,5 & 26,2 & 17,6 & 22,3 & 15,5 & 20,4 & 15,0 & 18,2 & 13,9 \\
\hline $30-100 x$ & 9,4 & 24,5 & 11,7 & 28,2 & 10,5 & 25,7 & 10,0 & 24,6 & 10,3 & 27,1 \\
\hline $100-200 x$ & 0,9 & 7,6 & 1,9 & 10,6 & 2,5 & 15,0 & 2,5 & 15,0 & 1,6 & 11,1 \\
\hline$>200 \mathrm{x}$ & 0,9 & 22,0 & 1,4 & 30,0 & 1,3 & 30,9 & 1,3 & 31,8 & 1,2 & 33,6 \\
\hline Összesen & 100,0 & 100,0 & 100,0 & 100,0 & 100,0 & 100,0 & 100,0 & 100,0 & 100,0 & 100,0 \\
\hline
\end{tabular}

Forrás: Nemzeti Statisztikai Hivatal.

Az 1970-es években az extenzív nagyvárosi növekedés lehetőségei kimerültek és megkezdődtek az átalakulási folyamatok a településhálózatban - agglomerálódás és konglomerálódás (erős kapcsolatok a szomszédos települések között, termelési komplexumok, s egyes esetekben rekreációs létesítmények jöttek létre). Az agglomerációk új területi típusai alakultak ki Bulgáriában (Szófia, Várna, Plovdiv, Burgasz, Pleven, Veliko Tirnovo). Ezekben a koncentráció és az urbanizáció sokkal gyorsabban zajlott, mint az ország többi részében (például, míg az ország népessége 1946 és 1985 között mintegy 20\%-kal növekedett, az agglomerációk megduplázták lakosságszámukat, s ugyanebben az időben az országban lévő termelőeszközök 70\%-a az említett területeken koncentrálódott). Ezekben az agglomerációkban olyan centripetális erők kezdtek el hatni, amelyek ide összpontosították a társadalom fö gazdasági és szociális funkcióit (Mladenov-Dimitrov 2009b).

Ebben az időszakban a nagy pontszerü és vonalas infrastruktúrafejlesztések eredményeként a városodás térben átalakult: az elszórtan elhelyezkedő csomópontokkal jellemezhető településhálózat vonalas-csomópont jellegü agglomerációs formává vált. Kirajzolódtak a Sztara Planina (Balkán-hegység) két oldalán párhuzamosan elhelyezkedö, nyugat-keleti irányú országos kommunikációs fötengelyek, müszaki 
infrastrukturális és gazdasági fejlődési tengelyek Szófia-Várna, illetve SzófiaBurgasz között. Ezek a tengelyek lettek a további urbanizációt, a népesség és a gazdaság koncentrációját elősegítő legfontosabb tényezők Bulgáriában. A meridionális struktúrák fejletlenek maradtak annak köszönhetően, hogy alulbecsülték a hosszú távú társadalmi-gazdasági változásokat az országterületen. A kialakított infrastrukturális hálózat felgyorsította az agglomerációs formációk és központjaik (a nagyobb városok) fejlődését. A nagyvárosok, az agglomerációk és az infrastrukturális tengelyek kiemelt fejlesztésére irányuló politika az urbanizáció túlfejlődéséhez és centrum-periféria problémák kialakulásához vezetett. Az utóbbi a településhálózat hierarchikus átalakulásában jelent meg. A nagyvárosok kiterjesztették vonzáskörzetüket - például Szófiáé 100 km-t is meghaladó sugarú körre növekedett, míg Plovdivé, Várnáé és Burgaszé 50 km, Rusze, Pleven és Sztara Zagora városoké 20-30 km lett stb. Azok a városok koncentrálták a közigazgatási, gazdasági és társadalmi funkciókat, váltak regionális fejlődési központokká, amelyeket fejletlen periféria vesz körbe. Mindezek leginkább a kisvárosokra voltak hatással éppúgy, mint az úgynevezett rurális központi településekre az ország határ menti és a hegyvidéki térségeiben. Kiterjedt perifériák alakultak ki a déli, a nyugati és részben az északi határ mentén, valamint a hegyvidéki régiókban. Ezekben a térségekben nem fejlődtek ki megfelelő méretü és funkciókkal ellátott központok, amelyek helyben tartották volna az elvándorlókat és megállították volna az elnéptelenedés folyamatát.

Az urbanizáció jelenlegi helyzetét jelentősen befolyásolják a globális, politikai és nemzetközi tényezők. A politikai rendszerváltásnak köszönhetően a településfejlödés gazdasági alapjai drámai módon megváltoztak. Hosszú idő óta fennálló kapcsolatok szakadtak meg, az ipari üzemek (és vidéki telephelyeik) sokasága zárt be, valamint megszünt a napi ingázás lehetősége. Mindezek együtt a térbeli fejlődés átalakulásához vezettek a városi és nem városi térségekben egyaránt. Az agglomerációk többsége nem müködött tovább, vagy legalábbis szűkült a mozgásterük a szuburbanizáció folyamatának gyengülésével.

A modern urbanizáció klasszikus jellemzői mellett néhány új trend és jellegzetesség is feltünt. Ezek a személyek, az áruk, a tőke és a szolgáltatások szabad áramlásának eredményeként következtek be, ami a városi és vidéki területek között az életkörülményekben tapasztalható különbségek eltünéséhez vezet. A gazdaság, a társadalmi tevékenységek, az infrastruktúra-fejlesztések stb. regionalizálódásának jellemzői megváltoztak, hatással voltak rájuk a hatalom és a politika különböző szintjei - a nemzeti és a nemzet feletti szint is.

Területi szempontból nézve, folytatódik a monocentrikus hierarchikus rendszer átalakulása egy hálószerü (csomópont-lineáris) rendszerré. Az átalakulást az infrastrukturális hálózatok különböző - lokális, regionális, nemzeti és nemzet feletti, sőt euroregionális - szintjei mozdítják elő. A közigazgatási funkciók továbbra is a monocentrikus szerkezetet erősítik, de a térbeli hierarchia új trendje is körvonalazódik, az újonnan megszerzett nemzeti és nemzet feletti vagy regionális funkcióknak megfelelően. Az európai típusú bolgár nagyvárosok (Szófia, Várna, Burgasz és Plovdiv) koncentrálják a nagy nemzeti és nemzetközi tőkét, kereskedelmet, személy- és 
információ-áramlásokat. A többi nagyváros, valamint a középvárosok különböző hálózatok (társadalmi szolgáltatások, szállítás, kommunikáció stb.) infrastrukturális csomópontjaiként fejlődnek.

Az urbanizáció másik modern jellemzője, hogy a kompakt város egyre nagyobb mértékben fejti ki befolyását a környező térségre. Ezt a befolyást úgy is leírhatjuk, mint a külső városi zóna „urbanizációs felszívása”. A központi tervutasításos gazdaság évei alatt ezeket a kevésbé urbanizált területeket tudatosan elnyomták. Napjainkban ezen területek iránt jelentős befektetői érdeklödés mutatkozik. Ennek eredményeképpen több nagyváros fő kivezető tengelyei mentén magasan „tőkésített” térségek jelennek meg. Az ilyen típusú szállítási útvonalak mentén, például Szófia körül számos ,,üzleti park” alakult ki, illetve különböző infrastrukturális és ipari beruházások, amelyek beleolvadtak a központi nagyvárosi területbe (az általános településrendezési terv szerint ez a térség 5,2\%-kal növekszik). Várna, Burgasz és Plovdiv esetében hasonló a helyzet - az első két esetben az üdülőövezet bővül, míg Plovdiv esetében a terjeszkedés a nagyobbrészt újonnan épített, szekunder szektorba tartozó beruházásoknak köszönhető.

A városok és a vidéki térségek között hagyományos kapcsolatok léteznek. A vidéki területek, gazdasági jelentőségük ellenére, nagyobb mértékben függnek ma a városokban működő gazdaságtól és szolgáltatásoktól, s ez mélyíti a „centrumperiféria” ellentétet (Grigorov 1994). Az EU különböző megoldásokkal igyekszik e problémát kezelni. A hatályos várospolitikák kidolgozásakor egyrészt a városokon belül, másrészt a városok és környezetük között az életminőségben tapasztalható különbségek csökkentése a cél. Ezen politikák lényege a periférikus (főleg vidéki) és más fejletlen régiók fejlődésének elösegítése. A politikák részei lehetnek környezetvédelmi intézkedések, a kulturális-történelmi örökség megőrzése, az identitástudat fenntartása és az újonnan városiasodott területek vonzó (természeti és ember alkotta) tulajdonságainak megjelenítése. A kevésbé városias térségek problémái visszavetik az öket magukban foglaló régiók fejlődését is.

\section{1. esettanulmány: Kis- és nagyon kis városok - városi központok Bulgária vidéki területein}

Az egyre inkább globalizálódó világban a fejlődést ma a városi települések erősödő szerepe és a városi lakosság koncentrációja jelzi. Ugyanakkor a kisvárosok is egyre fontosabbá válnak a regionális és a helyi fejlődés szempontjából, mint az urbanizáció helyi központjai.

A dokumentumok tanúsága szerint Bulgária vidéki területein községek találhatók, amelyek közigazgatási központjai 30 ezernél kisebb lakosságszámú és km²-enként 150 fönél kisebb népsürüségü települések. Így a vidéki területeken található az ország községeinek legnagyobb része (a 265-böl 233). A 10 ezer és 30 ezer közötti lakosságszámú városok kisvárosoknak, a 10 ezernél kisebb lélekszámú városok nagyon kis városoknak minősülnek. 
Az ország városi településeinek több mint $80 \%$-a vidéki területeken található (3. táblázat). Az 1992 és 2008 közötti időszakban számuk növekedett, de lakosságszámuk csökkent. Az ország lakosságának mintegy 19\%-a kisvárosokban és nagyon kis városokban él (2008). E városok különböző funkciókkal rendelkeznek. 44 kisváros és 135 nagyon kis város községi központ, vagyis közigazgatási funkcióik vannak. A községi központoknak szolgáltató funkcióik is vannak. Vannak olyan városok, amelyek turisztikai, ipari, közlekedési központok, mások a mezőgazdasági termelés központjai vagy határállomások. Sok kisváros egynél több funkcióval rendelkezik.

\section{TÁBLÁZAT}

Városi települések száma és a városi lakosság nagysága a vidéki területeken (Number of Urban Settlements and Urban Population in Rural Areas)

\begin{tabular}{|c|c|c|c|c|c|c|c|}
\hline & & \multicolumn{2}{|c|}{1992} & \multicolumn{2}{|c|}{2001} & \multicolumn{2}{|c|}{2008} \\
\hline & & össz. & $\begin{array}{l}\text { a vidéki } \\
\text { területe- } \\
\text { ken }\end{array}$ & össz. & $\begin{array}{l}\text { a vidéki } \\
\text { területe- } \\
\text { ken }\end{array}$ & össz. & $\begin{array}{l}\text { a vidéki } \\
\text { területe- } \\
\text { ken }\end{array}$ \\
\hline \multirow{3}{*}{$\begin{array}{l}\text { Városi } \\
\text { települé- } \\
\text { sek }\end{array}$} & Száma (db) & 238 & 192 & 240 & 195 & 253 & 207 \\
\hline & $\begin{array}{l}\text { Lélekszám (ezer } \\
\text { fö) }\end{array}$ & 5705 & 1563,8 & 5474,5 & 1513,5 & 5402,6 & 1458,7 \\
\hline & $\begin{array}{l}\text { Részesedés a teljes } \\
\text { lakosságszámból } \\
(\%)\end{array}$ & 67,3 & 18,4 & 69 & 19,1 & 71 & 19,2 \\
\hline \multirow{4}{*}{$\begin{array}{l}\text { Kisváro- } \\
\text { sok } \\
(10-30 \text { e. } \\
\text { lakos) }\end{array}$} & Száma (db) & 53 & 52 & 49 & 48 & 45 & 44 \\
\hline & $\begin{array}{l}\text { Részesedés az } \\
\text { összes városi tele- } \\
\text { pülésből (\%) }\end{array}$ & 22,3 & 21,8 & 20,4 & 20 & 17,8 & 17,4 \\
\hline & $\begin{array}{l}\text { Lélekszám (ezer } \\
\text { fó) }\end{array}$ & 882,6 & 869,2 & 823 & 809,6 & 738,9 & 725,8 \\
\hline & $\begin{array}{l}\text { Részesedés a teljes } \\
\text { városi lakosság- } \\
\text { számból }(\%)\end{array}$ & 15,4 & 15,2 & 15 & 14,8 & 13,7 & 13,4 \\
\hline \multirow{4}{*}{$\begin{array}{c}\text { Nagyon } \\
\text { kis váro- } \\
\text { sok } \\
\text { (10 e. } \\
\text { lakos alatt) }\end{array}$} & Száma (db) & 151 & 140 & 158 & 147 & 175 & 163 \\
\hline & $\begin{array}{l}\text { Részesedés az } \\
\text { összes városi tele- } \\
\text { pülésből (\%) }\end{array}$ & 63,4 & 58,8 & 65,8 & 61,2 & 69,2 & 64,4 \\
\hline & $\begin{array}{l}\text { Lélekszám (ezer } \\
\text { fö) }\end{array}$ & 734,3 & 694,6 & 741,6 & 703,9 & 773,7 & 732,9 \\
\hline & $\begin{array}{l}\text { Részesedés a teljes } \\
\text { városi lakosság- } \\
\text { számból (\%) }\end{array}$ & 12,9 & 12,2 & 13,5 & 12,9 & 14,3 & 13,6 \\
\hline
\end{tabular}

Forrás: a Nemzeti Statisztikai Hivatal adatai alapján a szerzők szerkesztése.

A vizsgált városok döntő többsége (90\%-a) lakosságszám csökkenést mutatott az 1992 és 2008 közötti időszakban. Mindössze 10\%-ukban nőtt a lakosságszám. A legtöbb ilyen város a Fekete-tenger partján, a Rodope-hegységben, a Sztruma folyó völgyében stb. helyezkedik el (1. ábra). A legnagyobb arányú lakosságszámcsökkenést az északnyugati országrész, Közép-Bulgária északi része, a Kraiste régió stb. vidéki térségeinek kis- és nagyon kis városai szenvedték el. A lakosságszám 
változása csekély vagy semmilyen hatást nem gyakorol a kis- és nagyon kis városok helyi fejlődésben játszott funkcióira és szerepére, inkább a gazdaságban érezhetők a hatások. A lélekszám csökkenése az elmúlt két évtizedben nem csupán a kis- és nagyon kis városokra jellemző, hanem az ország egészének városi lakosságára.

\section{1. ÁBRA}

A lélekszám változásának átlagos mértéke a vidéki területek kis- és nagyon kis városaiban (1992-2008, \%)

(Average Rate of Population Increase of Small and Very Small Towns in Rural Areas [1992-2008, \%])

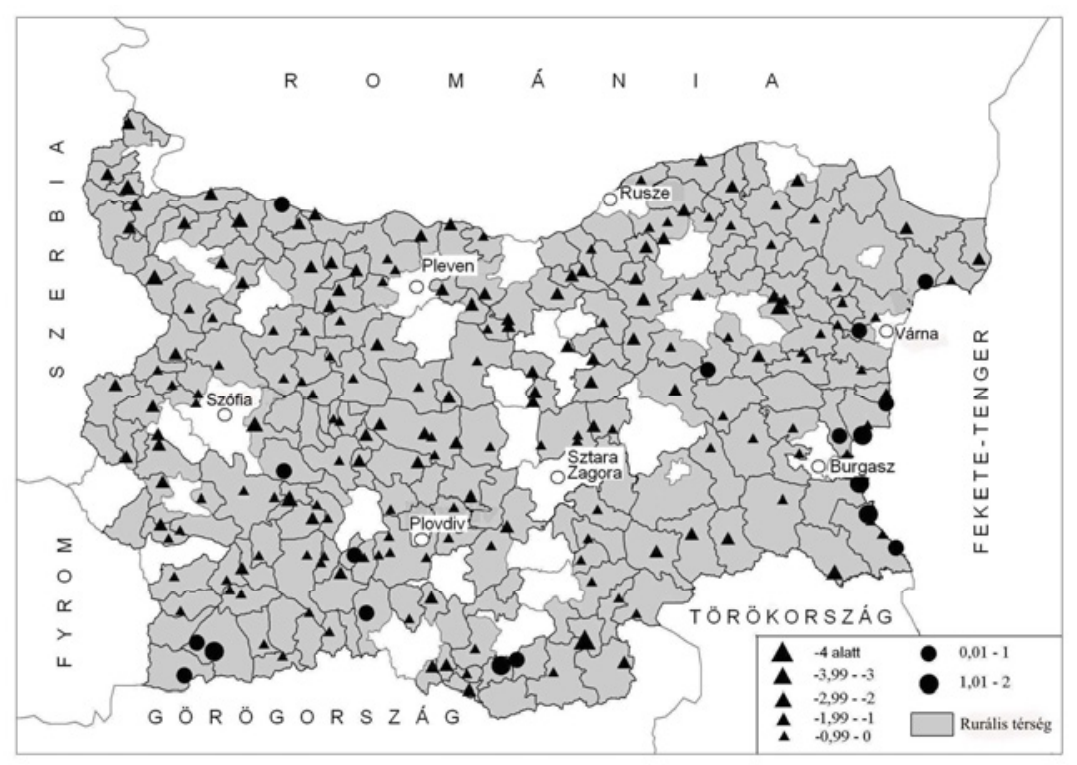

Forrás: a Nemzeti Statisztikai Hivatal adatai alapján a szerzők szerkesztése.

A csökkenő lakosságszám a bolgár lakosság egészére jellemző kedvezőtlen demográfiai folyamatok eredménye. A születési arányszámok a vidéki területek kisvárosaiban $(1992$ - 11,8\%o; 2008 - 10,7\%o) és nagyon kis városaiban (1992 $11,4 \%$; 2008 - 10,3\%o) hasonlóan alakulnak, mint az ország városi településeinek összességét tekintve $(1992$ - 10,6\%o; 2008 - 10,8\%o). Társadalmi-gazdasági és demográfiai tényezők befolyásolják leginkább a lakosság reprodukciós aktivitását. Bár a mutatószámok emelkedni kezdtek az elmúlt években, nem közelítik meg az 1990-es évek elejének értékeit. Az átlagosnál magasabb születési arányszámok az alábbi területek kis- és nagyon kis városaira jellemzők: a Fekete-tenger partvidéke, a Kelet-Marica bányavidéke, a Sztruma és a Meszta folyó völgye, illetve egyes etnikai és vallási csoportok magas arányával jellemezhető egyéb városok. A legnagyobb arányú a születésszám-csökkenés Északnyugat-Bulgária, Közép-Bulgária északi része, a Sztara Planina-hegység keleti térsége és a Rodope-hegység keleti vonulatainak városai körében. 
A vizsgált kategóriába tartozó városokban a lakosság halálozási arányszámai nőttek az 1992-2008 közötti időszakban. Ez a trend amúgy az ország összes városi településére jellemző. Eltérőek a halálozási arányszámok a kisvárosokban (1992 $10,1 \%$; 2008 - 12,4\%o), illetve a nagyon kis városokban $(1992$ - 12,3\%o; 2008 - 14,3\%o). A kisvárosokra jellemző halálozási ráták hasonlóak az ország egészében a városi településekre jellemző értékekhez (1992 - 9,7\%o, 2008 - 12,1\%o), míg a nagyon kis városokban magasabb ez az érték, ugyanakkor még mindig alacsonyabb, mint a falvakban (1992 - 12,1\%o; 2008 - 20,4\%o). A halálozási arányszámok emelkedését figyelhetjük meg minden városban, függetlenül azok földrajzi elhelyezkedésétől, funkcióitól, lakosságának nemzetiségi összetételétől stb.

A kérdéses időszak elején a kisvárosoknak pozitív volt a természetes szaporulata, a nagyon kis városoknak viszont negatív (2. ábra). Később a tendenciák megváltoztak, és negatív irányba fordult a természetes szaporulat mindegyik várostípus esetében, 2001-gyel kezdődően. Az együttható értékei kedvezőbbek a kérdéses időszak vége felé, de az emelkedő halálozási arányszámok miatt nem javul számottevően a demográfiai helyzet, különösen a nagyon kis városokban.

\section{2. ÁBRA}

A népesség természetes szaporulata a vidéki területek kis-és nagyon kis városaiban (1992-2008, \%o)

(Natural Increase of the Population of Small and Very Small Towns in Rural Areas [1992-2008, \%o])

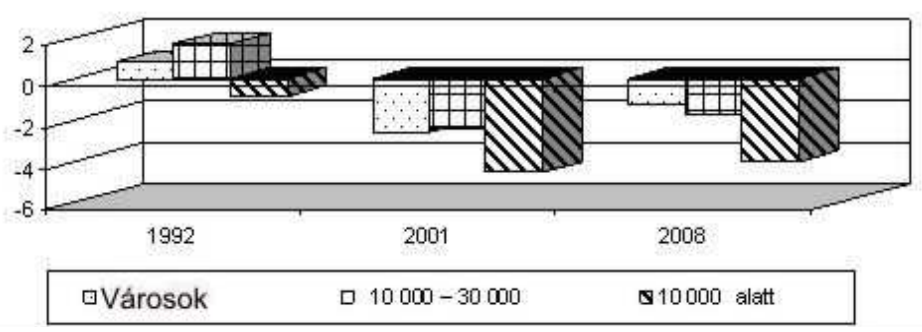

Forrás: Nemzeti Statisztikai Hivatal.

A vidéki területeken a kis- és nagyon kis városok több mint felében pozitív volt a népesség természetes szaporulata a kérdéses időszak elején (3. ábra), az időszak végére ugyanakkor már csak 25\%-ukban volt ez a helyzet (4. ábra). Ezek többnyire a legmagasabb születési arányszámokat felmutató városok. 


\section{3. ÁBRA}

A népesség természetes szaporulata a vidéki területek kis- és nagyon kis városaiban (1992, \%o) (Natural Increase of the Population of Small and Very Small Towns in Rural Areas [1992, \%o])

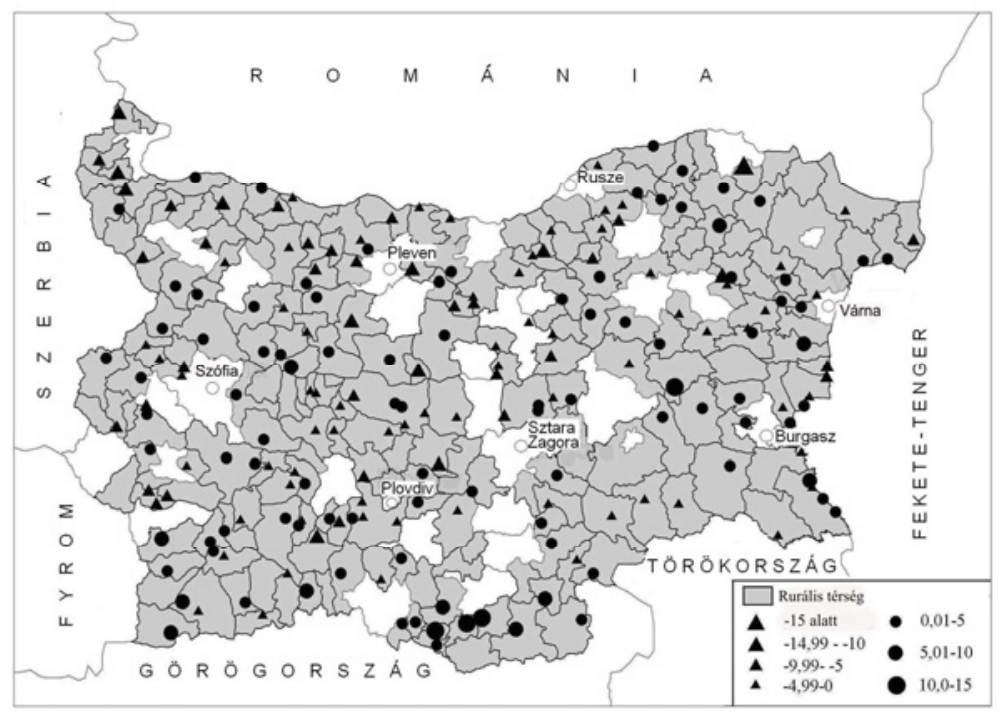

Forrás: a Nemzeti Statisztikai Hivatal adatai alapján a szerzők szerkesztése.

\section{4. ÁBRA}

A népesség természetes szaporulata a vidéki területek kis- és nagyon kis városaiban (2008, \%o) (Natural Increase of the Population of Small and Very Small Towns in Rural Areas [2008, \%o])

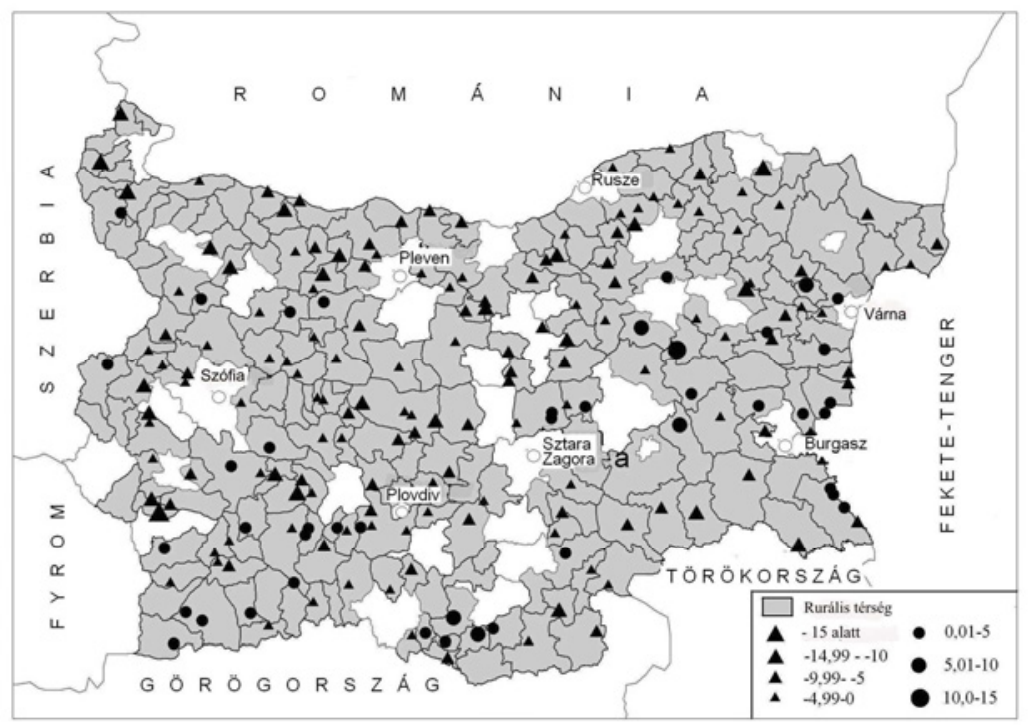

Forrás: a Nemzeti Statisztikai Hivatal adatai alapján a szerzők szerkesztése. 
A migráció változása a belföldi vándorlások alapján becsülhető csak meg (az egyes városok külső vándorlási adatai nem állnak rendelkezésre).

A vidéki területek nagyon kis városai a nagyobb városokba és az igazi nagyvárosokba történő vándorlás forrásai voltak a vizsgált időszak egészében, míg a kisvárosok csak mostanában váltak azzá (5. ábra). A kisvárosok ugyanakkor a más településekröl érkezők számára vonzásközpontot is jelentenek. A pozitív vándorlási egyenleget felmutató városok száma csökkent - a városok közel feléröl (1992) mintegy negyedére (2008). Pozitív vándorlási egyenleget 2008-ban az alábbi területek városaiban tapasztalhatunk: a Fekete-tenger partvidéke, Szófia, Plovdiv, Várna vonzáskörzetének városai, a Sztruma folyó völgyében fekvő városok stb.

\section{5. ÁBRA}

A lakosság vándorlási nyeresége a vidéki területek kis-és nagyon kis városaiban (\%o) (Migration Increase of the Population in Small and Very Small Towns in Rural Areas [\%o])

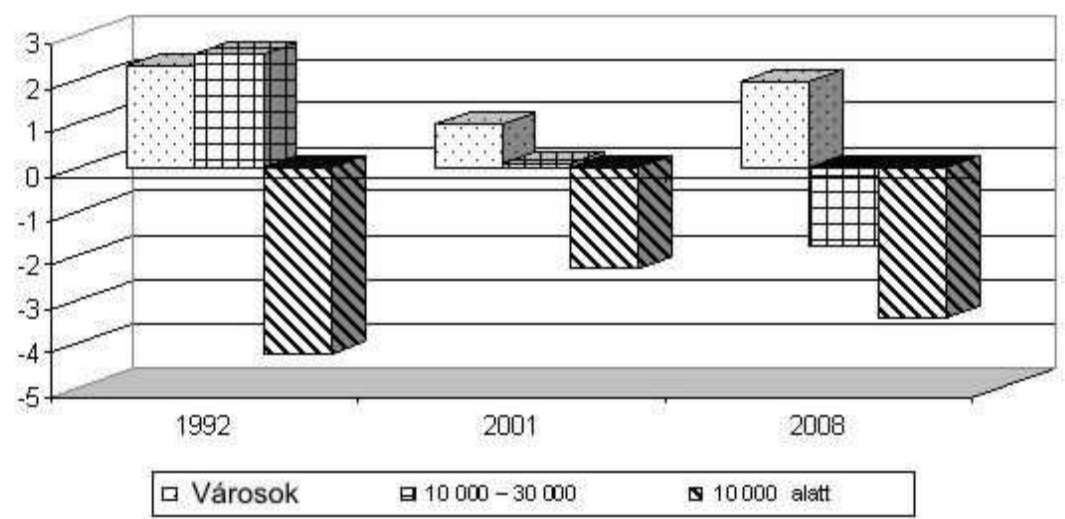

Forrás: a Nemzeti Statisztikai Hivatal adatai alapján a szerzők szerkesztése.

\section{2. esettanulmány: a Fekete-tenger vidékének urbanizációja a posztkommunista idöszakban}

Mivel a „tengerparti” települések nem hivatalos kategória, azok meghatározása szubjektív módon lehetséges. Esetünkben azokat a (városi és vidéki) településeket tekintjük tengerpartinak, amelyek vagy közvetlenül a parton fekszenek, vagy a szárazföld felé haladva az „első övezet” települései közé tartoznak és nincs közvetlen tengeri kijáratuk, de a part közvetlen közelében helyezkednek el, s ahonnan zavartalanul és gyorsan (15 percnél rövidebb idő alatt) elérhető a tengerpart, illetve a parti üdülő- vagy iparvárosok. Más szóval, tengerpartiak mindazok a települések, amelyek a part menti viszonylag keskeny sávban helyezkednek el, és amelyek részben vagy teljes egészében a tengertől, annak elérhetőségétől függnek (a halászati tevékenység, tengerparti turizmus, tengeri kereskedelem stb. jelenti létalapjukat). 
Az előzőek szerint lehatárolt parti zónába összesen 82 település tartozik (2009 év végi állapot, beleértve a városi és a vidéki településeket is): számos tengerparti üdülőhely (amelyek vagy nem rendelkeznek település státusszal, vagy úgynevezett „nemzeti jelentőségü település-formáció” pozíciójuk van), település-formációk (a lakott területek különleges kategóriája), kempingek, továbbá számos hétvégi házas övezet, (jogi státusz nélküli) halásztelepülés stb. A legtávolabbi „tengerparti” települések 25 kilométerre találhatók a tengertől a várnai agglomerációban, többnyire a Várna-Sumen-Szófia föútvonal mentén helyezkednek el, amely gyors elérhetőséget biztosít az agglomeráció központja és a tengerpart felé. A bolgár feketetengeri partvidék legdélebbi része (a Strandzsa Hegység partvidéke) felé haladva ugyanakkor a legkeskenyebb a tengerparti övezet a ritka településhálózat és a szárazföldi települések egy részének a tengerpart felöl való rossz megközelíthetősége miatt (a földrajzi közelség ellenére).

Az elmúlt 20 év során (a kommunizmus bukását követő időszakban) a bolgár Fekete-tenger partvidékén folyamatosan nőtt a lakosságszám, az ország egésze lakosságszámával ellentétben. A népszámlálási és a jelenlegi demográfiai adatok szerint az 1992-es év elején regisztrált 656633 föről 658979 före (2001 márciusára), illetve 670000 körülire 2008 végére. Bár nem jelentős a növekedés, a lakosság számának abszolút értékben történő emelkedése egyértelmüen mutatja, hogy a Bulgáriát sújtó demográfiai válság ellenére az országnak ezt a részét sokkal kevésbé érintették a negatív demográfiai folyamatok, mint az ország egészét. Sőt, pozitív demográfiai folyamatokat is képes volt felmutatni (a lakosságszám növekedése, nemek és korcsoportok szerinti összetétel stb.). A bolgár partvidéken ma már az ország teljes lakosságának csaknem 9\%-a él, bár a parti települések az ország teljes településállományának csak 1,6\%-át teszik ki. Ez természetesen a parti övezet két legnagyobb városának - Várna és Burgasz - tudható be, ahol a partvidék lakosságának 3/4-e él, és amelyek a négy legnagyobb bolgár város között vannak.

Az urbanizáció folyamata (a városi lakosság számának és arányának növekedése) a Fekete-tenger partvidékén három eltérő módon következett be:

1) falvak városokhoz történő csatolása

2) a település jogállásának változása (várossá nyilvánítás)

3) a városi lakosság számának növekedése (bevándorlás és/vagy természetes szaporodás).

A közeli falvak hozzácsatolása a városokhoz vagy a falvak egyszerü külvárosi területté nyilvánítása mindig is egy terület városodását szolgáló „eszköz” volt. A külvárosként beolvasztott falvak többnyire olyan települések, amelyek pozitív demográfiai fejlődést mutatnak, és szorosan kapcsolódnak a közeli városhoz (a munkaerő napi ingázása, közlekedés stb. révén). A bolgár Fekete-tengeri partvidék esetében ez a mechanizmus müködött több esetben például a burgaszi régióban, ahol 6 városközeli falu lett külvárossá nyilvánítva az elmúlt két évtized során. Ennek ellenére a hivatalos statisztikák szerint nem emelkedett a város lakosságának száma, a lélekszám stagnál, ami azt jelenti, hogy Burgasz külvárosainak esetében az urbanizáció csak a városi népesség arányának emelkedését jelenti. Így a tengerparti 
terület városi népességének aránya elérte a 92\%-ot (míg az országos átlag csak $70 \%$ ), noha a parti települések döntő többsége (háromnegyede) rurális település. A magas arány csak Várna és Burgasz városoknak köszönhető. A legfrissebb hivatalos statisztikai adatok azonban néha félrevezetőek lehetnek, mivel már nem kötelező (a kommunista időszak gyakorlatától eltérően) bejelenteni a címváltozást (lakcímváltozást), de ha van is ilyen elöírás, annak nem tesz eleget a beköltözők nagy része. Ezért elsősorban a legnagyobb városok esetében (Szófia, Várna, Burgasz stb.) valószínüsíthető, hogy hivatalos lakosságszámuk elmarad a „valós” számtól.

A település jogállásának megváltoztatása, faluból várossá történő nyilvánítása tipikus urbanizációs eszköz volt a kommunista Bulgáriában. A folyamat folytatódott a demokráciára és piacgazdaságra történő áttérés éveiben is. A Fekete-tenger partvidékén található városi települések az ország összes városi településének mindössze 5\%-át jelentik. Ugyanakkor a 17 új bolgár városi településből 5 település tengerparti. Ez két okra vezethető vissza: 1) az elmúlt évek tengerparti turizmusában tapasztalható fellendülésre, amely javított a gazdasági és demográfiai helyzeten, így megnövelte több üdülőhely lélekszámát, illetve 2) arra a jogi szabályozásra, amely lehetővé teszi, hogy a jelentős turisztikai funkciókkal és infrastruktúrával rendelkező vidéki települések pályázhassanak a városi jogállásra mindössze 1000 állandó lakosságszám elérését követően (míg más településeknél a lakosságszám-küszöb 3500 fö). Ennek megfelelően a 2000-es évek közepétől Kiten, Szveti Vlasz, Aheloj és Csernomorec falvak - mind a dél-bolgár tengerparton - megkapták a városi jogállást és ma a legfiatalabb bolgár városoknak számítanak. Ezen falvak lakosságszáma, Kiten kivételével, jóval meghaladta a 2000 föt már a várossá nyilvánítás időpontjában. Az egyetlen tengerparti falu, amely nem jelentős a vízparti turizmus szempontjából, mégis megkapta a városi jogállást, Akszakovo (a várnai agglomeráció része), amely a várossá nyilvánítás időpontjára az egyik legnépesebb bolgár falu volt a maga mintegy 7500 lakosával.

Azoktól a településektől eltekintve, amelyek már hozzájárultak a tengerparti terület urbanizálódásához (mind a városi lakosság számának, mind arányának növelése által), van még több nagy falu, amelyeket vagy Várna és Burgasz külvárosává lehet nyilvánítani, vagy megkaphatják a városi jogállást mint 1000 főnél több állandó lakossal rendelkező üdülőhelyek: ilyen például Ravda, amely a várossá nyilvánítás minden feltételének eleget tesz. Ha ez megtörténik, a teljes partvonal mentén, Lozenec üdülőfalutól (amely Burgasztól délre 50 km-re fekszik) Kranevo faluig (Várnától északra), Skorpilovci falu kivételével nem marad falusi település.

Két nagy agglomeráció létezik Bulgária tengerparti övezetében (és azon kívül) - a várnai agglomeráció és a burgaszi agglomeráció. A várnai agglomeráció a második legnagyobb városi képződmény Bulgáriában - a teljes tengerparti lakosság több mint fele itt él -, és az ország egyik leggyorsabban növekvő városi területe (nem hivatalos adatok szerint lakosainak száma közel félmillió). Friss felmérések szerint Várna város a legjobb lakóhelynek számít Bulgáriában. Az agglomeráció részét képezi négy városi település, számos falu, hétvégi házas övezet és tengerparti üdülőhely. Föleg nyugat felé terjeszkedik (a Várna-Szófia főútvonal mentén), illetve északkeleti irányban. A másik agglomeráció - Burgaszé - jóval kisebb, de még így is az egyik legnagyobb 
Bulgáriában (4. a rangsorban), több mint 200 ezer ember otthonául szolgál. Ugyanakkor a hivatalos adatok szerint Burgasz lakosságszáma stagnál, Várnáéval ellentétben (amely egyébként az egyetlen olyan bolgár város volt, melynek lakosságszáma nőtt a két népszámlálás között a hivatalos adatok szerint).

\section{6. ÁBRA}

A városi települések fejlödési dinamikája (1992-2008) és új városok a Fekete-tenger parti sávjában

(Dynamics of the Population of Urban Settlements [1992-2008] and New Towns in the Black Sea Coastal Zone)

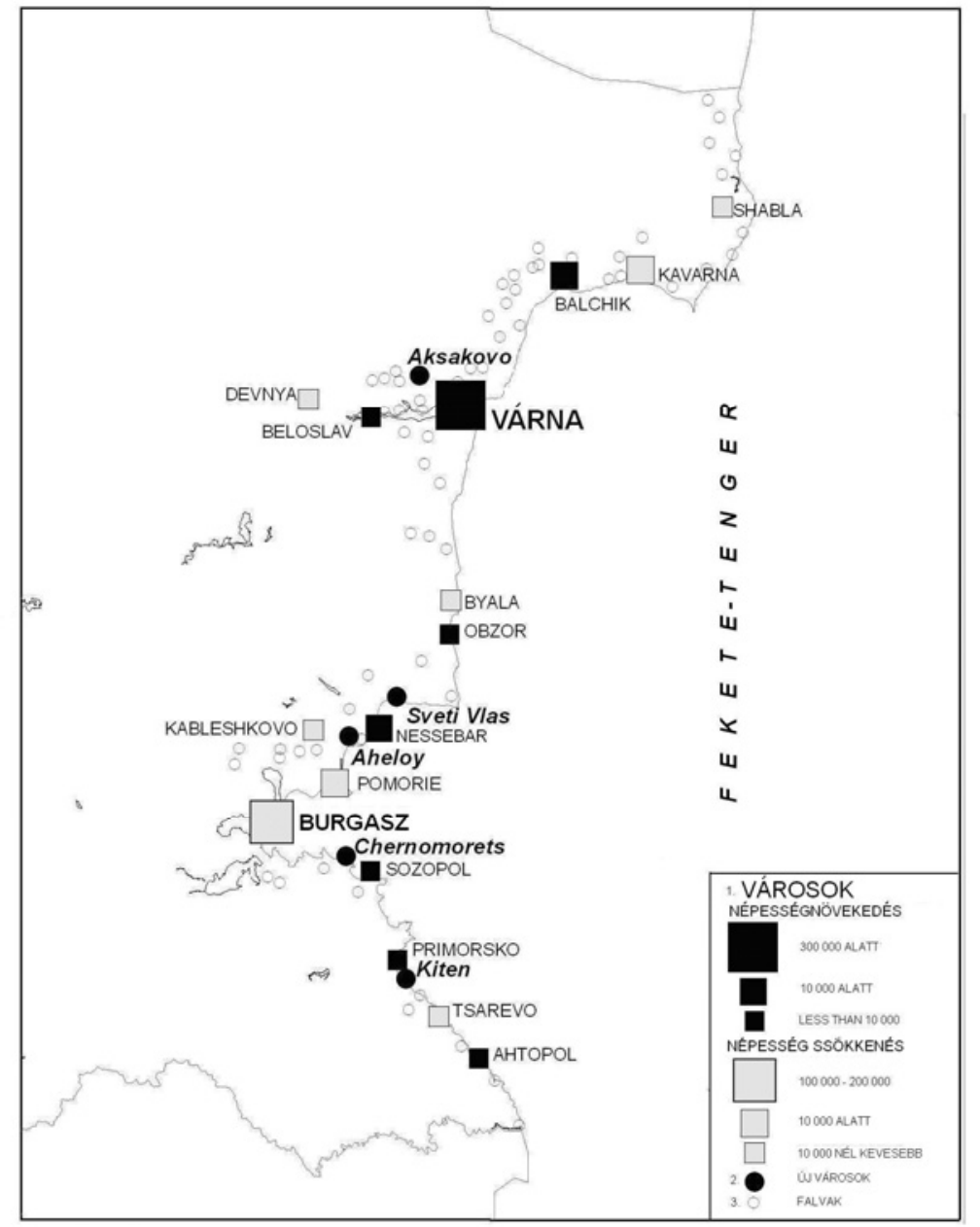

Forrás: Saját szerkesztés.

A nagy agglomerációkon kívül még egy agglomeráció alakult ki a posztkommunista időszak éveiben, ez pedig a nesszebári agglomeráció (amely hivatalosan nem minősül agglomerációnak). Sokkal kisebb az előző kettőnél (mintegy 20000 lakosa van), itt a 
legmagasabb (30\% feletti) a relatív lélekszám-növekedés a vizsgált időszakban, és itt található a négy új tengerparti (üdülő)város közül kettő, illetve a legnagyobb bolgár tengerparti üdülőhely - a Napospart (amelynek becsült kereskedelmi szálláshelykapacitása meghaladja a 200000 férőhelyet). Az agglomeráció részét képezik kisvárosok, falvak és tengerparti üdülőhelyek, amelyek szó szerint egymáshoz épültek, és így egy egyedülálló kompakt parti városi területet hoztak létre. Ennek a kis, de fontos agglomerációnak a lélekszám-növekedése elsősorban a bevándorlásnak köszönhető (az ország más részeiből ideköltözőknek), és csak kisebb részben a lakosság természetes szaporodásának. (A bevándorlásból, illetve a természetes szaporodásból eredő növekmény egymáshoz viszonyított aránya mintegy 9:1 a vizsgált időszak egészét tekintve.)

A Fekete-tengeri övezetnek az összességében pozitív demográfiai fejlődése ellenére vannak olyan részei (nem is kevés település, az összes városi település 1/3-a), ahol nem ilyen kedvező a helyzet. A negatív demográfiai trendek, amelyek a parti fekvéstől függetlenül érintik ezeket a településeket, az egész országra jellemző társadalmi-gazdasági okokra vezethetők vissza. A legtöbb esetben a negatív trendek a kevésbé fejlett turizmussal rendelkező településeket sújtják, valamint azokat a településeket, amelyek egy közeli nagyváros „,vonzási árnyékában” vannak, „sínylődnek" és persze néhány (a fontosabb idegenforgalmi és/vagy ipari központokhoz, valamint infrastrukturális tengelyekhez képest) periférikus fekvésű települést.

\section{Az urbanizáció következményei}

1) A kiterjedt területeket érintő szuburbanizációs folyamat segít bizonyos mértékben a „centrum-periféria” probléma megoldásában a nagy és közepes méretü városok vonzáskörzetében. E folyamat végeredménye a falvak és városok közti különbségek eltűnése.

2) Az új iparágak a vonzóbb perifériákra települnek a nem urbanizálódott vidéki területeken, vagy a városhatárok közvetlen közelébe.

3) Egyre iparszerübbé válik a mezőgazdaság, amely a vidéki környezetre jellemző hagyományos ökológiai értékek eltünéséhez vezet.

4) A nagy földterületet igénylő tevékenységek olyan helyen telepednek meg, ahol viszonylag alacsonyak a földárak.

5) A városi övezetek perifériáján üzleti parkok vagy ipari parkok épülnek (Szófia, Várna stb.).

6) A globalizáció és az új technológiák következtében az ide vándorlók és az újonnan letelepedők a nagyvárosokban koncentrálódnak.

7) Negatív demográfiai trendek (házasságkötések és válások száma, halálozási arányszám stb.).

8) A földhasználatra nehezedő nyomás és a földárak emelkedése a könnyen megközelíthető területeken.

9) Nagyobb ingázási távolságok és hosszabb ingázási idő. 
10) A települések képének megváltozása és a közlekedési és infrastruktúrarendszerek fejlődése.

11) A folyamatok szabályozásának szükségessége az agglomerációkban és a legmagasabb szintủ központokban, mint például: az ipari koncentráció csökkentése; az ipari és a vidéki területek közötti különbségek megörzése; védőövezetek kialakítása a városok és az agglomerációk között; a müszaki infrastruktúra fejlesztése az agglomerációban zajló folyamatok zavartalanságának biztosítására.

\section{Összefoglalás}

Globálisan nézve a tőke, az erőforrások és a termelő tevékenységek dekoncentrációja az urbanizált területek növekedéséhez, a lakosságnak a városokban történö koncentrációjához és a mezőgazdasági foglalkoztatottság csökkenéséhez vezet. Ennek eredménye a lakosság mobilitásának növekedése, azonban ez többnyire a legnagyobb városokban és azok külvárosi területein történő népességkoncentrációhoz vezet. Az urbanizációs folyamatnak e területekre történő koncentrációja (területi szempontból) összetett településalakzatok kialakulásához vezet, amelyek különbözö funkcionális jellemzőkkel rendelkeznek. Az urbanizációs folyamat lineáris folyamat, amely a közlekedéshez és annak infrastruktúrájához, mint a müszaki haladás hordozójához kötödik. A fontosabb közlekedési útvonalak mentén új települések jelennek meg, amelyek különböző funkcionális szerkezetủ városokat magukban foglaló mono- és policentrikus települési agglomerációkba szerveződnek. Nem egyértelmü, hogy a globalizáció következtében a városhálózat milyen formái jelennek majd meg a jövőben, hiszen maga a globalizáció is összetett és kiszámíthatatlan folyamat, így megjósolhatatlan a településekre gyakorolt társadalmi-gazdasági és geostratégiai hatása is.

Fordította: Hardi Tamás és Raffay Zoltán

\section{Jegyzet}

${ }^{1}$ Egyéb vonatkozó dokumentumok, adatforrások

Unified territorial-arrangement plan of the Republic of Bulgaria. Complex scientific-research and planning institute for spatial arrangement, urban planning and architecture, Sofia 1997 (in Bulgarian)

National strategy for regional development - 2007-2015, Ministry of regional development and public works, Sofia 2005

Decree № 7 for rules and norms of the arrangement of the various types of areas and arrangement zones Ministry of regional development and public works, Sofia 2003

Statistical yearbook. National Statistical Institute, Sofia 2007

Population and demographic processes, National Statistical Institute: 2001-2008

Census of the population, housing and farms in 2001, volume $1 / 3$ - Population by districts, municipalities and settlements, National Statistical Institute, Sofia 2001 


\section{Irodalom}

Grigorov, N. (1994) Teritorialnovo i celistnovo ustrojestvo na Republika Bulgarija do 2010 goda i sled neja. (Territorial and settlements arrangement of the Republic of Bulgaria till 2010 and later). National Center for Territorial Development and Housing Planning. Sofia.

Kopralev, I. (red.) (2002) Geografija na Blgarija. Forkom, Sofia.

Kopralev, I. (2007) Svremenni projavlenija na urbanizacionnite procesi v Bulgarija (na promera na golemitye bulgarski gradove). [Modern manifestation of urbanization processes in Bulgaria (based on the example of large Bulgarian cities).] - Problems of Geography. 3-4. 147-156. o.

Mladenov, Ch.-Dimitrov, E. (2009a) Urbanizacionnijat proces v Bulgarija prez perioda ot kraja na Vtorava cvetovija vojna do nasi dni. [The urbanization process in Bulgaria in the period between the end of World War Two and modern days]. - Geografija [Geography]. 3. 20-24. o.

Mladenov, Ch.-Dimitrov, E. (2009b) Urabnizacijata v Bulgarija ot Ocvobozsdenievo do kraja na Vtorava cvetovna vojna. [The urbanization in Bulgaria from the Liberation till the end of World War Two]. - Geografija [Geography]. 1. 13-17. o. 